\title{
Relationships between serum HER2 ECD, TIMP-1 and clinical outcomes in Taiwanese breast cancer
}

\author{
Hsiu-Pei Tsai ${ }^{1,2}$, Shin-Cheh Chen ${ }^{2}$, Huei-Tzu Chien ${ }^{3}$, Yi-Yin Jan², Tzu-Chieh Chao ${ }^{2}$, Miin-Fu Chen ${ }^{2}$ and \\ Ling-Ling Hsieh ${ }^{4^{*}}$
}

\begin{abstract}
Background: Serum levels of the extracellular domain of HER2/neu (HER2 ECD) have been demonstrated to be associated with clinical outcomes. A disintegrin and metalloproteinase-10, a sheddase of HER2/neu, can drive cancer progression and its activity is inhibited by tissue inhibitor of metalloproteinase-1 (TIMP-1). However, elevated TIMP-1 expression has been associated with a poor prognosis of breast cancer. Therefore, this study was performed to explore the relationships between serum HER2 ECD, TIMP-1 and clinical outcomes.

Methods: One hundred and eighty-five female breast cancer patients, who received curative mastectomy without neo-adjuvant chemotherapy at Chang-Gung Memorial Hospital, were recruited with informed consent for this study. Pre-operative serum levels of HER2 ECD and TIMP-1 were measured using an enzyme-linked immunosorbent assay.

Results: Twenty-three cases (12.4\%) were classified HER2 ECD positive. HER2 ECD positivity was significantly associated with age, lymph node involvement, histological grade, estrogen receptor status, progesterone receptor status, tissue HER2/neu overexpression, and disease-free survival (DFS). In an age, stage, ER and HER2/neu status matched subgroup $(\mathrm{N}=41)$, the serum level of TIMP-1 was significantly associated with HER2 ECD positivity and DFS.
\end{abstract}

Conclusions: A high serum TIMP-1 was significantly associated with HER2 ECD positivity and a poorer DFS among Taiwanese primary breast cancer patients with HER2 overexpression.

Keywords: breast cancer, HER2 ECD, TIMP-1, enzyme-linked immunosorbent assay, prognosis

\section{Background}

Amplification or overexpression of HER2/neu, a 185 $\mathrm{kDa}$ transmembrane tyrosine kinase receptor, has been reported in $20-30 \%$ of invasive breast cancers (IBCs) [1]. It predicts a more aggressive clinical course such as a transition from in situ growth to invasion [2], aggressive disease progression and poor treatment response [3-5]. In addition, it has been shown that there is a high concordant HER2/neu status in paired primary tumor and distant metastatic lesions on analysis by both immunohistochemistry (IHC) and by fluorescence in situ hybridization (FISH) [6-9]. Therefore, HER2/neu status is an important diagnostic and prognostic biomarker and is also one of the most dependable criteria for the use of trastuzumab-based chemotherapy to treat breast cancer.

\footnotetext{
* Correspondence: Ilhsieh@mail.cgu.edu.tw

${ }^{4}$ Department of Public Health, Chang Gung University, Tao-Yuan, Taiwan Full list of author information is available at the end of the article
}

In addition to HER2/neu status of the tumor tissue, the extracellular domain (ECD) of HER2 (HER2 ECD), which is shed from the HER2/neu receptor after a proteolysis process, has been shown to show a better correlation with tumor burden, treatment response, disease-free status and overall survival than the full-length HER2/neu [10]. However, certain clinical studies have not supported baseline serum HER2 ECD as a reliable predictor of tumor progression, treatment response, duration of response, or time to progression in advanced/metastatic breast cancer [11,12]. Thus, in agreement with the 2007 and 2009 American Society of Clinical Oncology guidelines on the use of biomarkers in breast cancer [11,13], there is currently insufficient evidence to support the use of serum HER-2 ECD in the routine management of individual patients with breast cancer.

It has been demonstrated that extracellular matrix remodeling proteinases, such as matrix metalloproteinases (MMPs), play a key role in the invasion and
Ciomed Central

(c) 2012 Tsai et al; licensee BioMed Central Ltd. This is an Open Access article distributed under the terms of the Creative Commons Attribution License (http://creativecommons.org/licenses/by/2.0), which permits unrestricted use, distribution, and reproduction in any medium, provided the original work is properly cited. 
metastasis of cancer cells [14-16]. Recent studies have indicated that members of a zinc-dependent family of proteinases related to the MMPs, namely disintegrin and metalloproteinases (ADAMs), are also involved in cancer progression [17]. A major level of control MMP functions occurs via their interaction with specific tissue inhibitors of metalloproteinases (TIMPs) [18]. Similar to MMPs, ADAM family members are also inhibited by specific TIMPs [17]. Among known MMPs and ADAMs, ADAM-10 has been shown to play an important role in the shedding of dozens of substrates that drive cancer progression, including HER2/neu $[19,20]$. Furthermore, HER2 ECD shedding can be inhibited by broad-spectrum metalloprotease inhibitors such as TAPI, batimastat, and TIMP-1 [19,21]. However, elevated TIMP-1 expression in human cancers, including breast cancer, has been associated with a decreased time to recurrence and a lower overall survival [22-26].

It is well known that there are significant ethnic disparities between western and eastern countries in terms of breast cancer with respect to cancer incidence, the frequency of BRCA1 and BRCA2 mutation, tumor biology and molecular subtypes [27-29]. In this context, information on the role of serum HER2 ECD in Asian breast cancer women is limited. Therefore, this study was performed to explore the relationships between serum HER2 ECD level, serum TIMP-1 level and clinical outcomes. Since MMP-2 and MMP-9 (gelatinase A and B) have been shown to be associated with breast cancer, expression of HER2/neu, and an unfavorable prognosis $[15,16]$ and because TIMP-2 also seems to have cell growth promoting and anti-apoptotic activity [30], serum MMP-2, MMP-9 and TIMP-2 were also included in the present analysis.

\section{Methods}

\section{Patients and Clinicopathological Information Collection}

This study was approved by the Institutional Review Board, Chang Gung Memorial Hospital (CGMH). One hundred and eighty-five female breast cancer patients received curative mastectomy without neo-adjuvant chemotherapy during 2001 and 2002 in CGMH and were retrospectively recruited with informed consent from our clinical sample library for this study. In order to have reasonable case numbers for studying the relationships between serum HER2 ECD and TIMP-1, the present cohort was intentionally comprised of most cases with HER2 overexpression. In addition, 23 women who came to CGMH for health examination during the same period and who were without cancer or other critical chronic disease, were also recruited with informed consent as normal controls. Clinicopathological information on the 185 breast cancer patients, including age, menopause status, echo-determined tumor size, lymph node metastasis, stage, DNA ploidy, SBR tumor grade, estrogen receptor status (ER), progesterone receptor status (PR), and HER2/neu evaluated by immunohistochemistry, regimens of treatment, disease-free and overall survival time, were collected.

\section{Analysis of Serum HER2 ECD, MMP-2, MMP-9, TIMP-1 and TIMP-2}

Serum was collected from the control individuals during their physical examination and from the breast cancer patients before surgery; the samples were then stored at $-70^{\circ} \mathrm{C}$ until they were assayed. The level of serum HER2 ECD was determined by enzyme-linked immunosorbent assay (ELISA) at Department of Clinical Pathology, CGMH, using two monoclonal antibodies that recognized a distinct epitope of the ECD of the HER2 protein as described previously [31]. All samples were assayed in duplicate. Since the mean value of the serum HER2 ECD of the 23 normal controls was $8.9 \mathrm{ng} / \mathrm{ml}$, we defined individuals with a HER2 ECD level higher than $8.9 \mathrm{ng} / \mathrm{ml}$ as HER2 ECD-positive.

Serum levels of MMP-2, MMP-9, TIMP-1 and TIMP2 were measured using a Biotrak ELISA System (Amersham Pharmacia Biotech Inc., USA). All samples were assayed in duplicate. According to the manufacture's protocol, $100 \mu \mathrm{l}$ of diluted serum samples were added to the assay and the levels of MMP-2, MMP-9, TIMP-1 and TIMP-2 were determined using appropriate peroxidase-conjugated anti- MMP-2, MMP-9, TIMP-1 and TIMP-2 antibodies. The reactions were stopped by the addition of $100 \mu \mathrm{l}$ of $1 \mathrm{M}$ sulfuric acid and absorbance of the product was read at $450 \mathrm{~nm}$ within 30 minutes.

\section{Statistical Analysis}

Statistical analysis was performed using SPSS version 11.0 (SPSS, Chicago, IL). The associations between the clinicopathological parameters and the HER2 ECD status were examined using the $\chi^{2}$-squared test or Fisher's exact test. Wilcoxon Rank Sums test and Fisher's exact test were used to compare all clinicopathological categories between the HER2 ECD positive and negative patients. Serum protease levels in the matched groups were also analyzed by the same methods. Survival curves were constructed using the Kaplan-Meier method and compared with the log-rank test (univariate analysis). Multivariate analysis was carried out using the Cox risk proportion model. A two-sided value of $p<0.05$ was considered statistically significant.

\section{Results}

Relationship between Baseline Serum HER2 ECD Levels and Clinicopathological variables

Pre-operative serum and complete clinicopathological information were retrospectively collected from 185 
patients receiving curative mastectomy between 2001 and 2002. Using the cut-off serum HER2 ECD level of $8.9 \mathrm{ng} / \mathrm{ml}$, which is the mean value for the 23 normalcontrol females, 23 (12.4\%) patients had serum HER2 ECD levels designated as positive. As shown in Table 1 HER2 ECD positivity was significantly associated with being older $(p=0.002)$, having lymph node involvement $(p=0.010)$, having an advanced stage $(p<0.0001)$, having a high histological grade $(p=0.029)$, the presence of non-diploid tumor DNA $(p=0.033)$, having a negative ER $(p=0.0002)$, having a negative $\operatorname{PR}(p=0.015)$ and HER2/neu overexpression $(p=0.003)$.

Table 1 The associations between serum ECD level and clinicopathological characteristics in $\mathbf{1 8 5}$ breast cancer patients

\begin{tabular}{|c|c|c|c|}
\hline Clinical parameters & $\begin{array}{c}E C D \\
\text { negative } \\
\mathrm{N}=162\end{array}$ & $\begin{array}{c}\mathrm{ECD} \\
\text { positive } \\
\mathrm{N}=23\end{array}$ & $\rho$ value \\
\hline \multicolumn{4}{|l|}{ Age (year-old) } \\
\hline$<=50$ & $91(94.8 \%)$ & $5(5.2 \%)$ & $0.002^{*}$ \\
\hline$>50$ & $71(79.8 \%)$ & $18(20.2 \%)$ & \\
\hline \multicolumn{4}{|l|}{ Tumor size $(\mathrm{cm})$} \\
\hline$<=3$ & $114(90.5 \%)$ & $12(9.5 \%)$ & 0.080 \\
\hline$>3$ & $48(81.4 \%)$ & $11(18.6 \%)$ & \\
\hline \multicolumn{4}{|l|}{ Lymph node status } \\
\hline Negative & $102(92.7 \%)$ & $8(7.3 \%)$ & $0.010^{*}$ \\
\hline Positive & $60(80.0 \%)$ & $15(20.0 \%)$ & \\
\hline \multicolumn{4}{|l|}{ Stage } \\
\hline 0 & $13(92.9 \%)$ & $1(7.1 \%)$ & $0.0001^{*}$ \\
\hline । & 37 (97.4\%) & $1(2.6 \%)$ & \\
\hline$\|$ & $95(90.5 \%)$ & $10(9.5 \%)$ & \\
\hline III & $17(60.7 \%)$ & $11(39.3 \%)$ & \\
\hline \multicolumn{4}{|l|}{ SBR grade } \\
\hline Low & 81 (92.0\%) & 7 (8.0\%) & $0.029^{*}$ \\
\hline High & $52(80.0 \%)$ & $13(20.0 \%)$ & \\
\hline \multicolumn{4}{|l|}{ DNA ploidy } \\
\hline Diploid & $40(95.2 \%)$ & $2(4.8 \%)$ & $0.033^{* a}$ \\
\hline Non-diploid & $69(80.2 \%)$ & 17 (19.8\%) & \\
\hline \multicolumn{4}{|c|}{ Estrogen receptor status (ER) } \\
\hline Negative & 93 (80.9\%) & $22(19.1 \%)$ & $0.0002^{* a}$ \\
\hline Positive $^{\dagger}$ & $69(98.6 \%)$ & $1(1.4 \%)$ & \\
\hline \multicolumn{4}{|c|}{$\begin{array}{l}\text { Progesterone receptor status } \\
\text { (PR) }\end{array}$} \\
\hline Negative & $107(83.6 \%)$ & $21(16.4 \%)$ & $0.015^{* a}$ \\
\hline Positive & 55 (96.5\%) & $2(3.5 \%)$ & \\
\hline \multicolumn{4}{|l|}{ HER2/neu expression (IHC) } \\
\hline Negative or Weak & $43(100.0 \%)$ & $0(0.0 \%)$ & $0.003^{* a}$ \\
\hline Strong $(>=3+)$ & $119(83.8 \%)$ & $23(16.2 \%)$ & \\
\hline
\end{tabular}

*statistically significant at $p<0.05$.

${ }^{+}$Monoclonal antibody $6 \mathrm{~F} 11$ was used as the primary antibody for ER IHC staining and the cutoff was set at $10 \%$ of tumor cells displayed staining to define "ER positive".

aby Fisher's exact test
Disease-free survival and overall survival (DFS and OS) were significantly worse in patients that were serum HER2 ECD positive at diagnosis when compared with patients that were HER2 ECD negative (Figure 1). To assess the effect of the other clinicopathological variables and treatment on DFS and OS, a Cox model was carried out initially using univariate analysis. Being older $(p=0.037)$, lymph node involvement $(p=0.003)$, negative ER status $(p=0.0008)$ and non-hormone therapy ( $p$ $=0.001)$ were significantly associated with a poorer DFS (Table 2). Lymph node involvement $(p=0.002)$, negative ER status $(p=0.002)$ and non-hormone therapy ( $p$ $=0.001)$ were significantly associated with a poorer OS (Table 2). A multivariate Cox regression model for DFS and OS was then built using the variables that were found to be significant during the univariate analysis and lymph node involvement and negative ER status were significantly associated with poorer DFS and OS. In addition, hormone therapy would seem to improve DFS and OS (Table 2).

\section{Relationship between Serum levels of MMPs, TIMPs and HER2 ECD}

To determine the type of protease associated with higher serum HER2 ECD levels, the serum levels of two metalloproteases (MMP-2 and MMP-9) and two protease inhibitors (TIMP-1 and TIMP-2) were analyzed within a matched design. Age, stage, ER and HER2/neu status were used for matching to rule out their effects on HER2 ECD positivity (Table 1 ). In the end nineteen HER2 ECD positive samples and twenty-two HER2 ECD negative samples were enough for this analysis. As shown in Table 3 the serum level of TIMP-1 was significantly higher in HER2 ECD positive patients compared to HER2 ECD negative patients. However, there were no significant differences between HER2 ECD positive and negative patients in terms of their serum MMP-2, MMP-9, and TIMP-2 levels.

\section{Combined Effect of Serum TIMP-1 and HER2 ECD Levels on Clinical Outcomes}

Since it has been reported that serum TIMP-1 was an independent predictive and prognostic factor for metastatic breast cancer [32], the effect of serum TIMP-1 and the combined effect of serum TIMP-1 and HER2 ECD on clinical outcomes was also explored using age, stage, ER and HER2/neu status matched patients (a total of 41 patients). The breast cancer patients were dichotomized into high and low TIMP-1 groups based on a median value of $270 \mathrm{ng} / \mathrm{mL}$. Patients with a low TIMP1 level and who were ECD negative were defined as the low-risk group, while the others were defined as the high-risk group. As shown in Figure 2, low serum TIMP-1 patients had significantly better DFS than high 

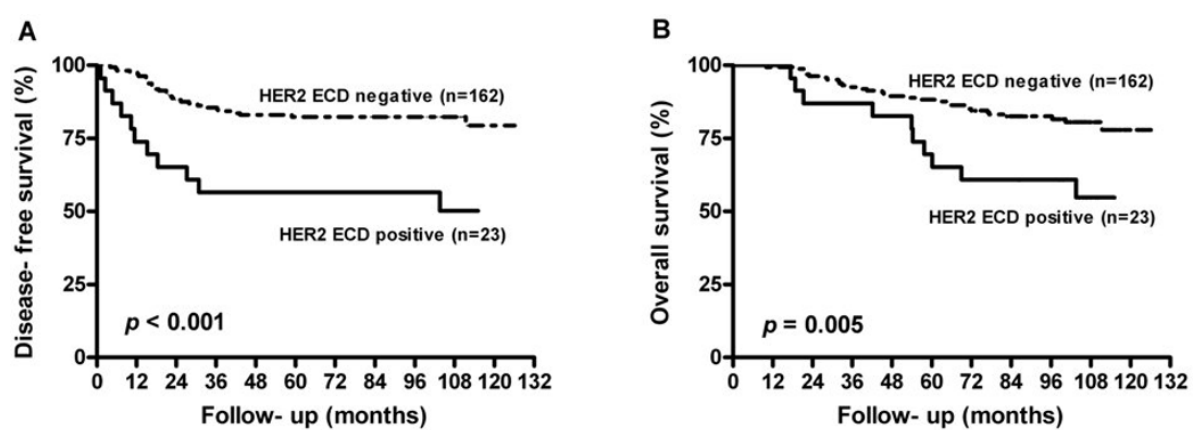

Figure 1 Kaplan-Meier curves for disease-free survival and overall survival based on the analysis of serum HER2 ECD positivity.

serum TIMP-1 patients $(p=0.039)$; however the effect of serum TIMP-1 on OS was insignificant $(p=0.215)$. Furthermore, the effects of serum TIMP-1 on clinical outcomes were strengthened when the serum HER2 ECD was taken into account.

\section{Discussion}

The clinical roles of serum HER2 ECD in breast cancer have been widely discussed since this protein was first discovered. The percentage of serum HER2 ECD positivity has been found to be extremely variable in primary breast cancer patients. In our study, HER2 ECD positivity was detected in $12.4 \%(23 / 185)$. This rate is close to the mean value of the worldwide studies published between 1992 and 2007 [12], although the cut-off value in our study $(8.9 \mathrm{ng} / \mathrm{mL})$ is different from the value $(15$ $\mathrm{ng} / \mathrm{mL}$ ) cleared by the US Food and Drug
Administration for use in the management of women with metastatic breast cancer [33].

High serum concentrations of HER2 ECD have been associated with HER2 overexpression [34], increased tumor burden [35], poorer survival [36] and resistance to endocrine therapy and chemotherapy $[12,37,38]$, We found that HER2 ECD positivity was significantly associated with most clinicopathological parameters including tumor size, lymph node involvement, tumor stage, histological grade, chromosome ploidy, ER, PR, and HER2/neu membrane protein overexpression. These results imply that serum HER2 ECD levels may reflect the aggressiveness of the disease better than tissue HER2/neu receptor only. It is interesting to note that older patients had higher HER2 ECD positivity than younger patients in this series of patients. This phenomenon can be explained by the differences in the

Table 2 Univariate and multivariate analysis of disease free survival and overall survival

\begin{tabular}{|c|c|c|c|c|c|c|}
\hline \multirow[t]{3}{*}{ Variables } & \multicolumn{3}{|c|}{ Disease-free survival } & \multicolumn{3}{|c|}{ Overall survival } \\
\hline & \multicolumn{2}{|c|}{$p$ value } & \multicolumn{4}{|c|}{$p$ value } \\
\hline & Univariate & Multivariate & $\mathrm{HR}^{\mathrm{a}}(95 \% \mathrm{Cl})$ & Univariate & Multivariate & $\mathrm{HR}^{\mathrm{a}}(95 \% \mathrm{Cl})$ \\
\hline \multirow[t]{2}{*}{ Age } & 0.037 & $0.205^{b}$ & $1.53(0.79-2.96)^{b}$ & 0.138 & & \\
\hline & & $0.278^{c}$ & $1.44(0.75-2.78)^{c}$ & & & \\
\hline Tumor size & 0.862 & & & 0.563 & & \\
\hline \multirow[t]{2}{*}{ Lymph node } & 0.003 & $0.003^{b}$ & $2.70(1.40-5.23)^{b}$ & 0.002 & $0.002^{b}$ & $2.81(1.46-5.42)^{b}$ \\
\hline & & $0.008^{c}$ & $2.41(1.25-4.64)^{c}$ & & $0.005^{c}$ & $2.57(1.34-4.93)^{c}$ \\
\hline ER & 0.0008 & $0.004^{b}$ & $3.79(1.53-9.38)^{b}$ & 0.002 & $0.004^{b}$ & $3.52(1.50-8.23)^{b}$ \\
\hline$P R$ & 0.109 & & & 0.168 & & \\
\hline HER2/neu & 0.997 & & & 0.619 & & \\
\hline Grade & 0.183 & & & 0.318 & & \\
\hline \multirow[t]{2}{*}{ ECD } & 0.0002 & $0.214^{b}$ & $1.62(0.76-3.47)^{b}$ & 0.005 & $0.451^{b}$ & $1.34(0.62-2.90)^{b}$ \\
\hline & & $0.097^{c}$ & $1.89(0.89-3.99)^{c}$ & & $0.341^{c}$ & $1.45(0.68-3.09)^{c}$ \\
\hline Chemotherapy* & 0.122 & & & 0.224 & & \\
\hline Radiation therapy & 0.418 & & & 0.859 & & \\
\hline Hormone therapy & 0.001 & $0.011^{c}$ & $0.31(0.13-0.77)^{c}$ & 0.001 & $0.004^{c}$ & $0.27(0.11-0.65)^{c}$ \\
\hline
\end{tabular}

* Anthracycline-based regimen (82/185, 44.3\%), CMF (cyclophosphamide, methotrexate and 5-fluorouracil) (64/185, 34.6\%), taxane (45/185, 24.3\%), trastuzumab $(22 / 185,11.9 \%)$, lapatinib $(3 / 185,1.6 \%)$ and others $(28 / 185,15.1 \%)$ were used as the first line adjuvant chemotherapy in this breast cancer cohort.

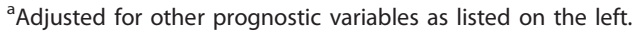

b, cSince most patients who were ER positive underwent hormone therapy, ER and hormone therapy were included in the model separately. 
Table 3 Differences in serum MMP-2, MMP-9, TIMP-1 and TIMP-2 levels $(\mathrm{ng} / \mathrm{mL}$ ) in the ECD positive/negative patients

\begin{tabular}{lccc}
\hline & $\begin{array}{c}\text { ECD negative } \\
\mathbf{N}=\mathbf{2 2}\end{array}$ & $\begin{array}{c}\text { ECD positive } \\
\mathbf{N}=\mathbf{1 9}\end{array}$ & $\boldsymbol{\rho}$ value $^{\mathbf{a}}$ \\
\hline MMP-2 & $685.09 \pm 148.30$ & $753.14 \pm 219.17$ & 0.359 \\
MMP-9 & $39.85 \pm 29.97$ & $40.82 \pm 33.66$ & 0.979 \\
TIMP-1 & $242.45 \pm 102.82$ & $364.88 \pm 139.38$ & 0.006 \\
TIMP-2 & $49.23 \pm 21.81$ & $62.92 \pm 42.11$ & 0.528 \\
\hline
\end{tabular}

aby Wilcoxon two-sample test. frequency of ER and PR negative tumors in different age groups of patients. In the present study, the frequencies of ER and PR negativity were significantly higher in older patients $(70.8 \%$ and $83.2 \%$ for ER and PR, respectively) than younger patients $(54.2 \%$ and $56.3 \%$ for ER and PR, respectively). The data from Taiwan Cancer Database also consistently shows that younger patients ( $\leq 50$ years) have a higher prevalence of ER and PR expression compared with older patients (> 50 years) [27].

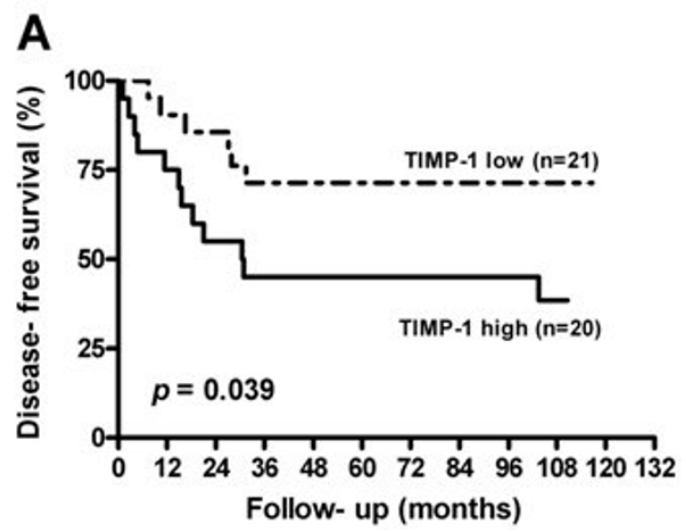

B
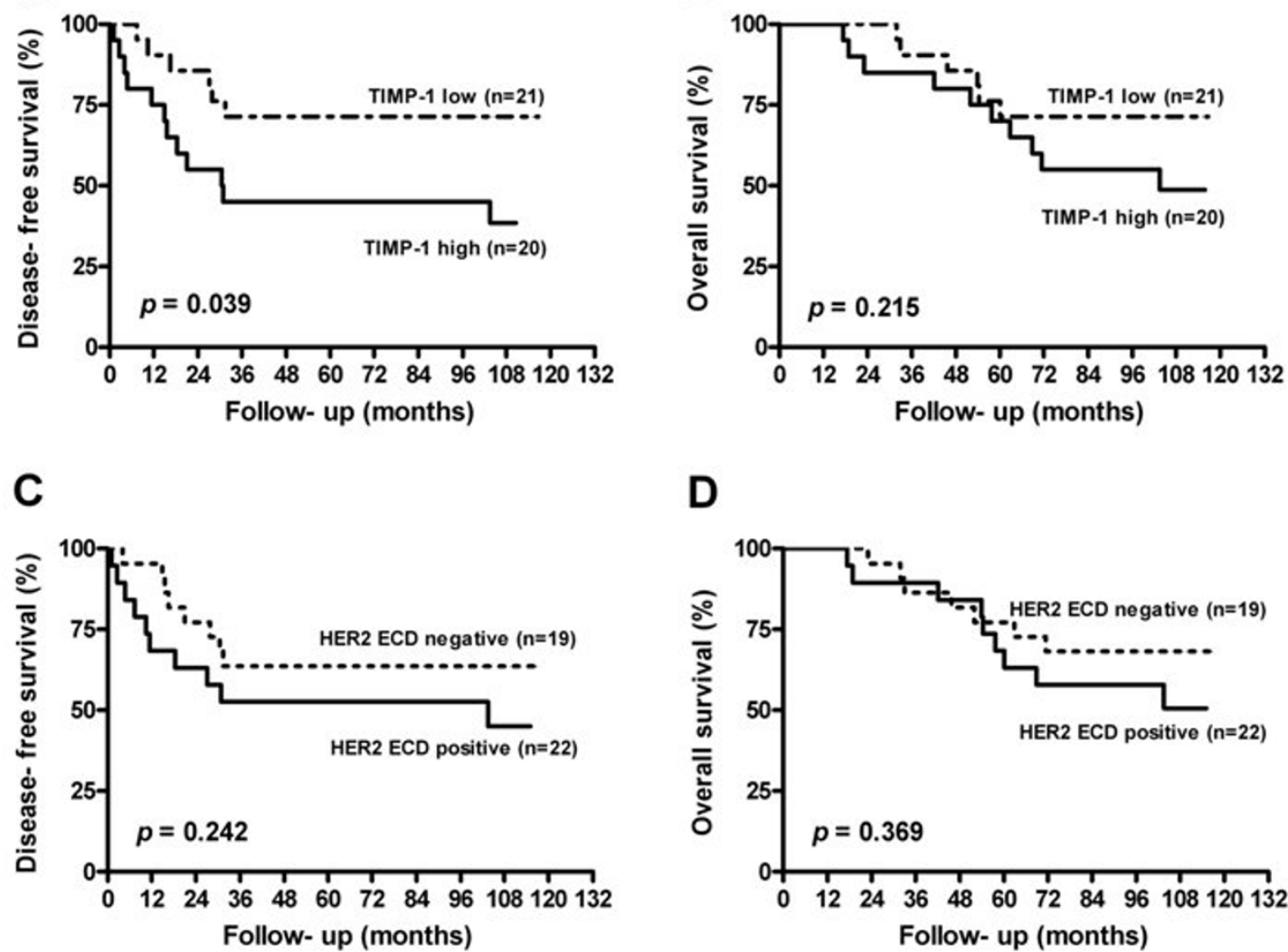

D
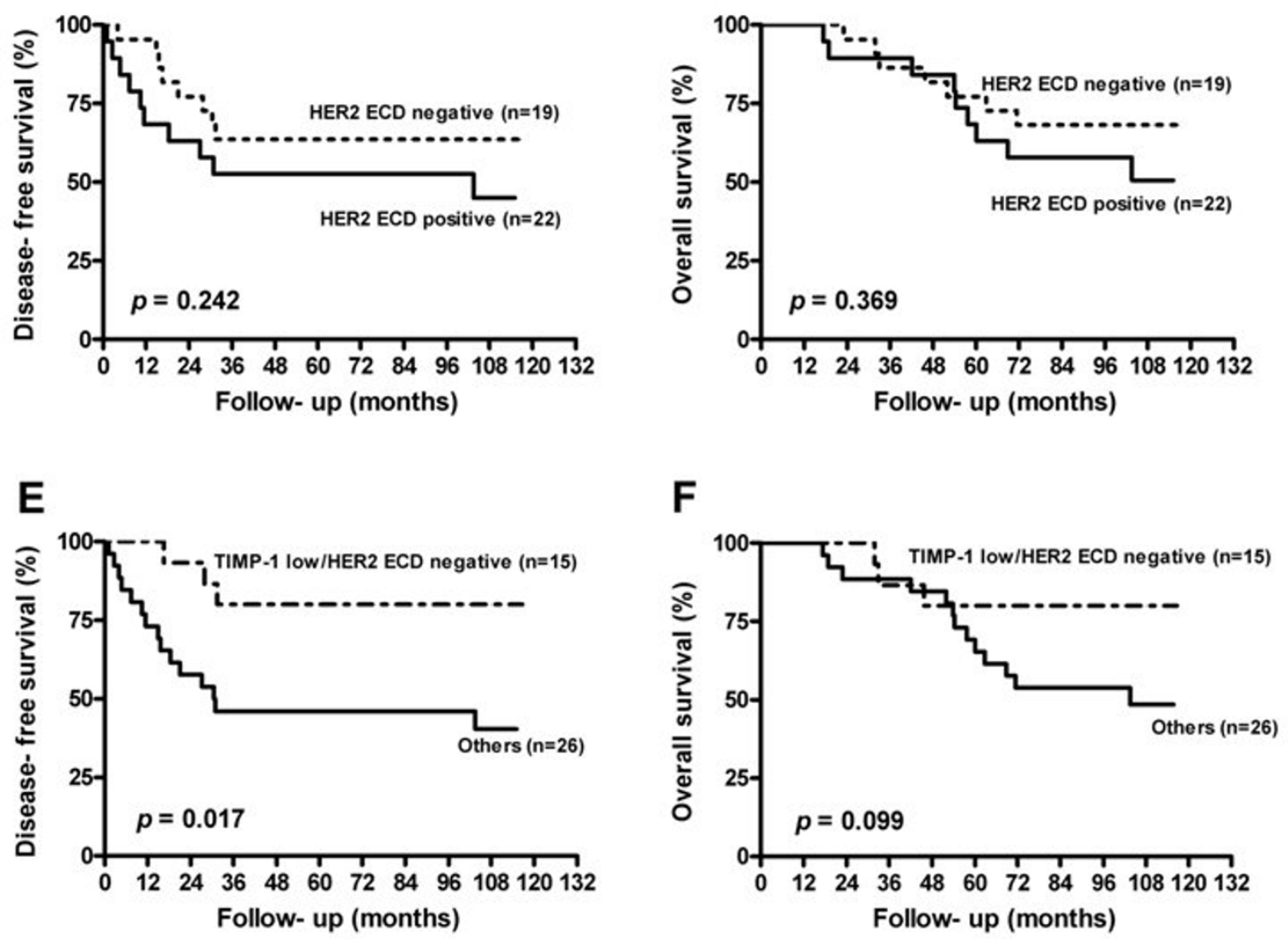

Figure 2 Kaplan-Meier curves for disease-free survival and overall survival based on the analysis of serum TIMP-1 level (A, B), HER2 ECD positivity (C, D) and their combination (E, F) in 41 age, stage, ER and HER2/neu status matched patients. 
A high serum HER2 ECD level has been shown to act as an independent prognostic marker in one study by Ludovini et al. [39]. In the present study, serum HER2 ECD positivity was also associated with shorter DFS and OS in the univariate analysis. Probably due to a small number of positive HER2 ECD cases $(n=23)$, these associations were not significant in the multivariate analysis (Table 2). However, serum HER2 ECD positivity was a better predictor than HER2/neu status by IHC as indicated by previous studies $[10,39]$.

The mechanism of HER2 ECD shedding from HER2/ neu receptor is not been completely understood. It had been demonstrated that HER2 is one of the shedding substrates of ADAM-10 [19] and HER2 ECD shedding can be enhanced by fatty acid synthase [40] and inhibited by the broad-spectrum metalloprotease inhibitors such as TAPI, batimastat, and TIMP-1 [21]. In this study, we found that serum levels of TIMP-1 were significantly higher in HER2 ECD positive patients compared to HER2 ECD negative patients after correction for various clinicopathological factors (age, stage, ER and HER2/neu status). This observation was unexpected and contrary to the findings of the in vitro model system $[21,41]$. TIMP-1 is the prototypic inhibitor for most MMP family members [42]. Recent studies, however, have indicated that TIMP-1 also possesses a broad range of MMP independent biological activities including the induction of proliferation and the inhibition of apoptosis [43]. The induction of proliferation and the inhibition of apoptosis by TIMP-1 have been demonstrated to occur through activation of the phosphatidyl inositol-3 kinase (PI-3K) signaling pathway [44-46]. Furthermore, activation of PI-3K can lead to activation of phosphatidyl inositol-dependent kinase-1 (PDK1), which directly phosphorylates ADAMs and causes EGFR activation [47]. Therefore, it is possible that in some circumstances a high level of TIMP-1 may activate ADAM-10, which would directly lead to HER2 ECD shedding. The double-edged sword of TIMP-1 in terms of activation and inhibition of ADAM-10 activity and the effect of this on HER2 ECD shedding needs further investigation.

Since Talvensaari-Mattila et al. [26] reported that high serum TIMP-1 levels are significantly correlated with poorer relapse-free survival among breast cancer patients, several studies have obtained similar findings [48]. In our small matched study subjects $(\mathrm{N}=41)$, adjuvant treatment was not different for the different TIMP-1 and HER2 ECD groups. We observed that high serum levels of TIMP-1 were associated with a poorer DFS, but not HER2 ECD (Figure 2). Furthermore, patients with a low TIMP-1 and a negative HER2 ECD had better clinical outcomes than the other combinations (Figure 2). This observation is similar to a study by Lipton et al. [49] They found that a combined analysis of both serum TIMP-1 and HER2/neu conferred an additional ability to predict subgroups of patients with significantly different clinical outcomes as compared to using either biomarker alone.

\section{Conclusions}

A high serum TIMP-1 was significantly associated with HER2 ECD positivity and a poorer DFS among Taiwanese primary breast cancer patients with HER2 overexpression. Combined analysis of both serum TIMP-1 and HER2 ECD may have additional value when used for the clinical management of breast cancer patients with HER2 overexpression in Taiwan.

\section{Abbreviations}

(HER2 ECD): extracellular domain of HER2/neu; (TIMP-1): tissue inhibitor of metalloproteinase-1; (DFS): disease-free survival; (IBCs): invasive breast cancers; (IHC): immunohistochemistry; (FISH): fluorescence in situ hybridization; (MMPs): matrix metalloproteinases; (ADAMs): a disintegrin and metalloproteinases; (ER): estrogen receptor; (PR): progesterone receptor; (ELISA): enzyme-linked immunosorbent assay; (OS): overall survival.

\section{Acknowledgements}

This Study was supported by Grant CMRPG 33010 from Chang Gung Memorial Hospital.

\section{Author details}

${ }^{1}$ Graduate Institute of Clinical Medical Sciences, Chang Gung University, TaoYuan, Taiwan. ${ }^{2}$ Department of General Surgery, Chang Gung Memorial Hospital, Tao-Yuan, Taiwan. ${ }^{3}$ Graduate Institute of Biomedical Sciences, Chang Gung University, Tao-Yuan, Taiwan. ${ }^{4}$ Department of Public Health, Chang Gung University, Tao-Yuan, Taiwan.

\section{Authors' contributions}

SCC and LLH conceived the study. HPT performed ELISA assay. SCC, YYJ, TCC and MFC collected the cases and clinical information. HPT, SCC and LLH interpreted the ELISA. HPT, HTC and LLH performed the statistical analysis. HPT performed the literature review and wrote the manuscript. LLH supervised the experiments and manuscript writing. All authors read and approved the final manuscript.

\section{Competing interests}

The authors declare that they have no competing interests.

Received: 18 November 2011 Accepted: 17 February 2012 Published: 17 February 2012

\section{References}

1. Freudenberg JA, Wang Q, Katsumata M, Drebin J, Nagatomo I, Greene MI: The role of HER2 in early breast cancer metastasis and the origins of resistance to HER2-targeted therapies. Exp Mol Pathol 2009, 87:1-11.

2. Roses RE, Paulson EC, Sharma A, Schueller JE, Nisenbaum H, Weinstein S, Fox KR, Zhang PJ, Czerniecki BJ: HER-2/neu overexpression as a predictor for the transition from in situ to invasive breast cancer. Cancer Epidemiol Biomarkers Prev 2009, 18:1386-1389.

3. Xu FJ, Stack S, Boyer C, O'Briant K, Whitaker R, Mills GB, Yu YH, Bast RC Jr: Heregulin and agonistic anti-p185(c-erbB2) antibodies inhibit proliferation but increase invasiveness of breast cancer cells that overexpress p185(c-erbB2): increased invasiveness may contribute to poor prognosis. Clin Cancer Res 1997, 3:1629-1634.

4. Tovey SM, Brown S, Doughty JC, Mallon EA, Cooke TG, Edwards J: Poor survival outcomes in HER2-positive breast cancer patients with lowgrade, node-negative tumours. Br J Cancer 2009, 100:680-683.

5. De Placido S, Carlomagno C, De Laurentiis M, Bianco AR: c-erbB2 expression predicts tamoxifen efficacy in breast cancer patients. Breast Cancer Res Treat 1998, 52:55-64. 
6. Henderson IC, Patek AJ: The relationship between prognostic and predictive factors in the management of breast cancer. Breast Cancer Res Treat 1998, 52:261-288.

7. Meng S, Tripathy D, Shete S, Ashfaq R, Haley B, Perkins S, Beitsch P, Khan A, Euhus D, Osborne C, et al: HER-2 gene amplification can be acquired as breast cancer progresses. Proc Natl Acad Sci USA 2004, 101:9393-9398.

8. Tsutsui S, Ohno S, Murakami S, Kataoka A, Kinoshita J, Hachitanda Y: Comparison of the immunohistochemical expression of EGFR, c-erbB2 and p53 protein between primary and recurrent breast cancer. Breast Cancer 2002, 9:111-117.

9. Simon R, Nocito A, Hubscher T, Bucher C, Torhorst J, Schraml P Bubendorf $L$, Mihatsch MM, Moch $H$, Wilber $K$, et al: Patterns of her-2/neu amplification and overexpression in primary and metastatic breast cancer. I Natl Cancer Inst 2001, 93:1141-1146.

10. Molina MA, Saez R, Ramsey EE, Garcia-Barchino MJ, Rojo F, Evans AJ, Albanell J, Keenan EJ, Lluch A, Garcia-Conde J, et al: $\mathrm{NH}(2)$-terminal truncated HER-2 protein but not full-length receptor is associated with nodal metastasis in human breast cancer. Clin Cancer Res 2002, 8:347-353.

11. Lennon S, Barton C, Banken L, Gianni L, Marty M, Baselga J, LeylandJones B: Utility of serum HER2 extracellular domain assessment in clinical decision making: pooled analysis of four trials of trastuzumab in metastatic breast cancer. J Clin Oncol 2009, 27:1685-1693.

12. Leary AF, Hanna WM, van de Vijver MJ, Penault-Llorca F, Ruschoff J, Osamura RY, Bilous M, Dowsett M: Value and limitations of measuring HER-2 extracellular domain in the serum of breast cancer patients. J Clin Oncol 2009, 27:1694-1705.

13. Harris L, Fritsche H, Mennel R, Norton L, Ravdin P, Taube S, Somerfield MR, Hayes DF, Bast RC Jr: American Society of Clinical Oncology 2007 update of recommendations for the use of tumor markers in breast cancer. Clin Oncol 2007, 25:5287-5312.

14. Page-McCaw A, Ewald AJ, Werb Z: Matrix metalloproteinases and the regulation of tissue remodelling. Nat Rev Mol Cell Biol 2007, 8:221-233.

15. Talvensaari-Mattila A, Paakko P, Turpeenniemi-Hujanen T: Matrix metalloproteinase-2 (MMP-2) is associated with survival in breast carcinoma. Br J Cancer 2003, 89:1270-1275.

16. Pellikainen JM, Ropponen KM, Kataja W, Kellokoski JK, Eskelinen M Kosma VM: Expression of matrix metalloproteinase (MMP)-2 and MMP-9 in breast cancer with a special reference to activator protein-2, HER2, and prognosis. Clin Cancer Res 2004, 10:7621-7628.

17. Murphy G: The ADAMs: signalling scissors in the tumour microenvironment. Nat Rev Cancer 2008, 8:929-941.

18. Deryugina El, Quigley JP: Matrix metalloproteinases and tumor metastasis. Cancer Metastasis Rev 2006, 25:9-34.

19. Liu PC, Liu X, Li Y, Covington M, Wynn R, Huber R, Hillman M, Yang G, Ellis $D$, Marando $C$, et al: Identification of ADAM10 as a major source of HER2 ectodomain sheddase activity in HER2 overexpressing breast cancer cells. Cancer Biol Ther 2006, 5:657-664.

20. Crawford HC, Dempsey PJ, Brown G, Adam L, Moss ML: ADAM10 as a therapeutic target for cancer and inflammation. Curr Pharm Des 2009, 15:2288-2299.

21. Codony-Servat J, Albanell J, Lopez-Talavera JC, Arribas J, Baselga J: Cleavage of the HER2 ectodomain is a pervanadate-activable process that is inhibited by the tissue inhibitor of metalloproteases- 1 in breast cancer cells. Cancer Res 1999, 59:1196-1201.

22. Gouyer V, Conti M, Devos P, Zerimech F, Copin MC, Creme E, Wurtz A, Porte $H$, Huet G: Tissue inhibitor of metalloproteinase 1 is an independent predictor of prognosis in patients with nonsmall cell lung carcinoma who undergo resection with curative intent. Cancer 2005, 103:1676-1684.

23. Schrohl AS, Holten-Andersen MN, Peters HA, Look MP, Meijer-van Gelder ME, Klijn JG, Brunner N, Foekens JA: Tumor tissue levels of tissue inhibitor of metalloproteinase- 1 as a prognostic marker in primary breast cancer. Clin Cancer Res 2004, 10:2289-2298.

24. Klintman M, Ornbjerg Wurtz S, Christensen IJ, Braemer Hertel P, Ferno M, Malmberg M, Mouridsen $H_{1}$ Cold F, Schrohl AS, Foekens JA, et al: Association between tumor tissue TIMP-1 levels and objective response to first-line chemotherapy in metastatic breast cancer. Breast Cancer Res Treat 2010, 121:365-371.

25. Kuvaja P, Talvensaari-Mattila A, Turpeenniemi-Hujanen T: High preoperative plasma TIMP-1 is prognostic for early relapse in primary breast carcinoma. Int J Cancer 2008, 123:846-851.
26. Talvensaari-Mattila A, Turpeenniemi-Hujanen T: High preoperative serum TIMP-1 is a prognostic indicator for survival in breast carcinoma. Breast Cancer Res Treat 2005, 89:29-34.

27. Lin CH, Liau JY, Lu YS, Huang CS, Lee WC, Kuo KT, Shen YC, Kuo SH, Lan C, Liu JM, et al: Molecular subtypes of breast cancer emerging in young women in Taiwan: evidence for more than just westernization as a reason for the disease in Asia. Cancer Epidemiol Biomarkers Prev 2009, 18:1807-1814.

28. McCracken M, Olsen M, Chen MS Jr, Jemal A, Thun M, Cokkinides V Deapen D, Ward E: Cancer incidence, mortality, and associated risk factors among Asian Americans of Chinese, Filipino, Vietnamese, Korean and Japanese ethnicities. CA Cancer J Clin 2007, 57:190-205.

29. Chen ST, Chen RA, Kuo SJ, Chien YC: Mutational screening of breast cancer susceptibility gene 1 from early onset, bi-lateral, and familial breast cancer patients in Taiwan. Breast Cancer Res Treat 2003, 77:133-143.

30. Hayakawa T, Yamashita K, Ohuchi E, Shinagawa A: Cell growth-promoting activity of tissue inhibitor of metalloproteinases-2 (TIMP-2). J Cell Sci 1994, 107(Pt 9):2373-2379.

31. Sugano K, Ushiama M, Fukutomi T, Tsuda H, Kitoh T, Ohkura H: Combined measurement of the c-erbB-2 protein in breast carcinoma tissues and sera is useful as a sensitive tumor marker for monitoring tumor relapse. Int J Cancer 2000, 89:329-336.

32. Lipton A, Ali SM, Leitzel K, Demers L, Evans DB, Hamer P, Brown-Shimer S, Pierce K, Carney W: Elevated plasma tissue inhibitor of metalloproteinase1 level predicts decreased response and survival in metastatic breast cancer. Cancer 2007, 109:1933-1939.

33. Cook GB, Neaman IE, Goldblatt U, Cambetas DR, Hussain M, Luftner D, Yeung KK, Chan DW, Schwartz MK, Allard WJ: Clinical utility of serum HER2/neu testing on the Bayer Immuno 1 automated system in breast cancer. Anticancer Res 2001, 21:1465-1470

34. Kong SY, Nam BH, Lee KS, Kwon Y, Lee ES, Seong MW, Lee do H, Ro J: Predicting tissue HER2 status using serum HER2 levels in patients with metastatic breast cancer. Clin Chem 2006, 52:1510-1515.

35. Beltran $\mathrm{M}$, Colomer R: Does HER-2 status predict only a decreased response to hormone therapy in advanced breast cancer, or does it also predict the extent of metastatic disease? J Clin Oncol 2002, 20:4605, author reply 4606 .

36. Fehm T, Gebauer $\mathrm{G}$, Jager W: Clinical utility of serial serum c-erbB-2 determinations in the follow-up of breast cancer patients. Breast Cancer Res Treat 2002, 75:97-106.

37. Lipton A, Ali SM, Leitzel K, Demers L, Chinchilli V, Engle L, Harvey HA Brady C, Nalin CM, Dugan M, et al: Elevated serum Her-2/neu leve predicts decreased response to hormone therapy in metastatic breast cancer. J Clin Oncol 2002, 20:1467-1472.

38. Colomer R, Llombart-Cussac A, Lluch A, Barnadas A, Ojeda B, Caranana V, Fernandez Y, Garcia-Conde J, Alonso S, Montero S, et al: Biweekly paclitaxel plus gemcitabine in advanced breast cancer: phase II trial and predictive value of HER2 extracellular domain. Ann Oncol 2004, 15:201-206.

39. Ludovini V, Gori S, Colozza M, Pistola L, Rulli E, Floriani I, Pacifico E, Tofanetti FR, Sidoni A, Basurto C, et al: Evaluation of serum HER2 extracellular domain in early breast cancer patients: correlation with clinicopathological parameters and survival. Ann Oncol 2008, 19:883-890

40. Vazquez-Martin A, Fernandez-Real JM, Oliveras-Ferraros C, Navarrete JM, Martin-Castillo B, Del Barco S, Brunet J, Menendez JA: Fatty acid synthase activity regulates HER2 extracellular domain shedding into the circulation of HER2-positive metastatic breast cancer patients. Int J Oncol 2009, 35:1369-1376.

41. Amour A, Knight CG, Webster A, Slocombe PM, Stephens PE, Knauper V, Docherty AJ, Murphy G: The in vitro activity of ADAM-10 is inhibited by TIMP-1 and TIMP-3. FEBS Lett 2000, 473:275-279.

42. Bourboulia D, Stetler-Stevenson WG: Matrix metalloproteinases (MMPs) and tissue inhibitors of metalloproteinases (TIMPs): Positive and negative regulators in tumor cell adhesion. Semin Cancer Biol 2010, 20:161-168.

43. Stetler-Stevenson WG: Tissue inhibitors of metalloproteinases in cell signaling: metalloproteinase-independent biological activities. Sci Signal 2008, 1:re6.

44. Akahane T, Akahane M, Shah A, Thorgeirsson UP: TIMP-1 stimulates proliferation of human aortic smooth muscle cells and Ras effector pathways. Biochem Biophys Res Commun 2004, 324:440-445. 
45. Liu XW, Bernardo MM, Fridman R, Kim HR: Tissue inhibitor of metalloproteinase-1 protects human breast epithelial cells against intrinsic apoptotic cell death via the focal adhesion kinase/ phosphatidylinositol 3-kinase and MAPK signaling pathway. J Biol Chem 2003, 278:40364-40372.

46. Liu XW, Taube ME, Jung KK, Dong Z, Lee YJ, Roshy S, Sloane BF, Fridman R, Kim HR: Tissue inhibitor of metalloproteinase-1 protects human breast epithelial cells from extrinsic cell death: a potential oncogenic activity of tissue inhibitor of metalloproteinase-1. Cancer Res 2005, 65:898-906.

47. Zhang Q, Thomas SM, Lui WW, Xi S, Siegfried JM, Fan H, Smithgall TE, Mills GB, Grandis JR: Phosphorylation of TNF-alpha converting enzyme by gastrin-releasing peptide induces amphiregulin release and EGF receptor activation. Proc Natl Acad Sci USA 2006, 103:6901-6906.

48. Wurtz SO, Schrohl AS, Mouridsen H, Brunner N: TIMP-1 as a tumor marker in breast cancer-an update. Acta Oncol 2008, 47:580-590.

49. Lipton A, Leitzel K, Chaudri-Ross HA, Evans DB, Ali SM, Demers L, Hamer P Brown-Shimer S, Pierce K, Gaur V, Carney W: Serum TIMP-1 and response to the aromatase inhibitor letrozole versus tamoxifen in metastatic breast cancer. J Clin Oncol 2008, 26:2653-2658.

doi:10.1186/1477-7819-10-42

Cite this article as: Tsai et al.: Relationships between serum HER2 ECD, TIMP-1 and clinical outcomes in Taiwanese breast cancer. World Journal of Surgical Oncology 2012 10:42.

\section{Submit your next manuscript to BioMed Central} and take full advantage of:

- Convenient online submission

- Thorough peer review

- No space constraints or color figure charges

- Immediate publication on acceptance

- Inclusion in PubMed, CAS, Scopus and Google Scholar

- Research which is freely available for redistribution

Submit your manuscript at www.biomedcentral.com/submit
Biomed Central 